\title{
Tumor necrosis factor-alpha promotes survival in methotrexate-exposed macrophages by an NF- $\kappa$ B-dependent pathway
}

\author{
Susan ZY Lo*, James H Steer, David A Joyce
}

\begin{abstract}
Introduction: Methotrexate (MTX) induces macrophage apoptosis in vitro, but there is not much evidence for increased synovial macrophage apoptosis in MTX-treated patients. Macrophage apoptosis is reported, however, during clinical response to anti-tumor necrosis factor-alpha (TNF- $\alpha$ ) treatments. This implies that TNF- $\alpha$ promotes macrophage survival and suggests that TNF- $\alpha$ may protect against MTX-induced apoptosis. We, therefore, investigated this proposal and the macrophage signaling pathways underlying it.

Methods: Caspase-3 activity, annexin-V binding/7-aminoactinomycin D (7-AAD) exclusion and cell-cycle analysis were used to measure steps in apoptosis of primary murine macrophages and cells of the RAW 264.7 macrophage cell line that had been exposed to clinically-relevant concentrations of MTX and TNF- $\alpha$.

Results: MTX induces apoptosis in primary murine macrophages at concentrations as low as $100 \mathrm{nM}$ in vitro. TNF- $\alpha$, which has a context-dependent ability to increase or to suppress apoptosis, efficiently suppresses MTX-induced macrophage apoptosis. This depends on NF- $\kappa$ B signaling, initiated through TNF Receptor Type 1 ligation. Macrophage colony stimulating factor, the primary macrophage survival and differentiation factor, does not activate NF- $\kappa$ B or protect macrophages from MTX-induced apoptosis. A weak NF- $\kappa$ B activator, Receptor Activator of NF- $\kappa B$ Ligand (RANKL) is likewise ineffective. Blocking NF- $\kappa B$ in TNF- $\alpha$-exposed macrophages allowed pro-apoptotic actions of TNF- $\alpha$ to dominate, even in the absence of MTX. MTX itself does not promote apoptosis through interference with NF- $\kappa \mathrm{B}$ signaling.
\end{abstract}

Conclusions: These findings provide another mechanism by which TNF- $\alpha$ sustains macrophage numbers in inflamed tissue and identify a further point of clinical complementarity between MTX and anti-TNF- $\alpha$ treatments for rheumatoid arthritis.

\section{Introduction}

Synovial inflammatory macrophages have a central role in maintaining disease activity in rheumatoid arthritis (RA). Macrophage numbers in tissue are regulated by recruitment, local proliferation, local cell death and emigration to draining lymph nodes [1,2]. Synovial macrophage apoptosis has also been observed in synovium in RA [3,4]. A suppressed rate of apoptosis would contribute to maintaining inflammatory macrophage numbers, and thus clinical activity, in macrophage-dependent conditions. An enhanced rate of synovial macrophage

\footnotetext{
* Correspondence: szylo40@gmail.com

Pharmacology Unit, School of Medicine and Pharmacology, University of Western Australia, 35 Stirling Highway, Crawley, Western Australia 6009, Australia
}

(0) 2011 Lo et al.; licensee BioMed Central Ltd. This is an open access article distributed under the terms of the Creative Commons Attribution License (http://creativecommons.org/licenses/by/2.0), which permits unrestricted use, distribution, and reproduction in any medium, provided the original work is properly cited. apoptosis is reported in RA patients responding to antiTNF- $\alpha$ treatments [4] as a delayed, rather than an early phenomenon [5]. Macrophage apoptosis has also been reported in patients with Crohn's disease after antiTNF- $\alpha$ treatment [6]. These observations suggest that TNF- $\alpha$ directly, or indirectly, sustains macrophage survival in these conditions.

TNF- $\alpha$ activity supports recruitment of macrophages into RA synovium [7], but is not known to enhance the proliferation of macrophages or to prevent the emigration of macrophages through lymphatics [2]. TNF- $\alpha$, however, may deliver either apoptotic or survival signals, depending on the cell context. TNF- $\alpha$ is a ligand for two related receptors, TNF-R1 (p55) and TNF-R2 (p75). Macrophages and their bone marrow and blood-borne 
progenitors express both receptors [8]. TNF- $\alpha$ ligation to TNF-R1 leads to assembly of a Death-Inducing Signaling Complex (DISC) and ultimately activation of downstream effector caspases-3/6/7. Where this is the dominant consequence of TNF-R1 ligation, apoptosis follows. In other circumstances, TNF-R1 initiates survival signaling [9] through activation of the NF- $\kappa \mathrm{B}$ pathway. TNF- $\alpha$ ligation to TNF-R1 can thus bring apoptosis or survival, depending on the relative activities generated in the DISC-initiated and NF- $\kappa$ B pathways [10]. Macrophage survival is notably dependent on NF- $\kappa \mathrm{B}$ signaling. The transcriptionally active RelA/NF$\kappa \mathrm{B}_{1}$ (p65/p50) complex appears in macrophage nuclei constitutively during late differentiation and is important for continuing survival $[10,11]$. In vivo, there is enhanced nuclear expression of RelA/NF- $\kappa \mathrm{B}_{1}$ in synovial macrophages in RA [12], consistent with a role for NF- $\kappa \mathrm{B}$ activity in maintaining macrophage survival.

The observations of enhanced apoptosis during antiTNF- $\alpha$ treatment imply that TNF- $\alpha$ predominantly antagonises apoptosis in RA and Crohn's disease $[4,6]$. On the other hand, methotrexate (MTX), an antirheumatic drug that has demonstrable pro-apoptotic effects on monocyte/macrophage cells in vitro, does not appreciably alter the synovial membrane macrophage apoptosis rate in RA patients $[3,13]$. This led us to question whether the presence of TNF- $\alpha$ in synovium was providing a survival signal to macrophages in MTXtreated patients, thus antagonizing one potential therapeutic function of MTX. That would provide additional explanation for the clinical complementarity of MTX and anti-TNF- $\alpha$ treatments in RA [14]. In the study of Catrina et al., which demonstrated synovial macrophage apoptosis in response to anti-TNF- $\alpha$ therapy, the majority of patients were co-treated with MTX [4].

MTX is a folate analogue with numerous effects on inflammatory cell proliferation and survival, cytokine expression, angiogenesis, cell adhesion and reactive oxygen production [15]. The known direct targets of MTX are dihydrofolate reductase, thymidylate synthase and 5-aminoimidazole-4-carboxamide ribonucleotide (AICAR) transformylase [15]. Consequences of inhibiting these enzymes include reduced availability of purines and pyrimidines for DNA and RNA synthesis and accumulation of AICAR. AICAR, by inhibiting enzymatic deamination of adenosine and adenosine monophosphate, is proposed to increase availability of adenosine extracellularly, for anti-inflammatory effect through adenosine cell surface receptors [16]. These effects are generally believed to be mediated by long-lived polyglutamate forms of MTX, which are generated in many cell types, including normal myeloid precursor cells and myelocytic cancer cells [17].

\section{Materials and methods Materials}

The Recombinant Macrophage-Colony Stimulating Factor (M-CSF) was obtained from R\&D Systems (Sydney, NSW, Australia). Annexin V conjugated to phycoerythrin (Annexin V-PE) and 7-amino-actinomycin (7-AAD) were from BD Biosciences (Sydney, NSW, Australia). Parthenolide was purchased from Alexis Biochemicals (Lausen, Switzerland). Rabbit anti-I $\kappa \mathrm{B} \alpha$ $(\mathrm{C}-21)$ polyclonal antibody, anti-NF- $\kappa \mathrm{B}$ p65, anti-NF- $\kappa \mathrm{B}$ p50, anti-c-Rel and anti-RelB were obtained from Santa Cruz Biotechnology, Santa Cruz, CA, USA. Mouse anti-phospho-I $\kappa \mathrm{B} \alpha$ (Ser32/36) (5A5) and horseradish peroxidase-conjugated anti-rabbit were from Amersham Biosciences (Sydney, NSW, Australia). Methotrexate was provided by Mayne Pharma Pty Ltd. (Adelaide, South Australia, Australia). Etanercept came from Wyeth Australia Pty Ltd. (Sydney, NSW, Australia). Recombinant GST-rRANKL was kindly provided by Ming-Hao Zheng and Jiake $\mathrm{Xu}$, Centre for Orthopaedic Research, University of Western Australia [18]. All other reagents were sourced from Sigma-Aldrich (Sydney, NSW, Australia), unless otherwise indicated.

\section{Cell culture}

RAW $_{264.7}$ cells were obtained from the American Type Culture Collection and maintained in Dulbecco's modified Eagle's medium (Life Technologies, Carlsbad, California, USA) with $10 \%$ low endotoxin fetal calf serum (CSL, Melbourne, Australia), penicillin and gentamicin (DMEM-FCS). Bone marrow-derived monocytes/ macrophages (BMDM) were collected from the femora and tibiae of eight-week old female C57BL or BALB/C mice, as previously described [19], with the approval of the Animal Ethics Committee of The University of Western Australia. Cells were expanded in M-CSF (30 ng/ $\mathrm{mL}$ )-supplemented DMEM-FCS for seven days at $37^{\circ} \mathrm{C} /$ $5 \% \mathrm{CO}_{2} / 95 \%$ air. The experiments reported here were conducted with BMDM from C57BL mice, but results were comparable using $\mathrm{BALB} / \mathrm{c}$ mice.

\section{MTT cytotoxicity assay}

Viability was estimated using the 3-(4,5-dimethyl-2-thiazolyl)-2,5-diphenyl-2H-tetrazoliumbromide (MTT) assay. BMDM $\left(3 \times 10^{4}\right.$ cells/well $)$ were seeded in 24-well plates in M-CSF-supplemented DMEM-FCS. After $48 \mathrm{hr}$, cells were treated with TNF- $\alpha$ for $3 \mathrm{hr}$, followed by MTX exposure for $24 \mathrm{hr}$. At the end of treatments, $50 \mu \mathrm{L}$ of MTT $(5 \mathrm{mg} / \mathrm{mL})$ was added to each well, and cells were incubated at $37^{\circ} \mathrm{C}$ for $2 \mathrm{hr}$. Formazan crystals were then solubilised with $150 \mu \mathrm{L}$ of $44 \%$ dimethyl formamide/20\% SDS at room temperature for at least 30 minutes on a rocking platform. A total of $100 \mu \mathrm{L}$ 
aliquots were quantitated at $550 \mathrm{~nm}$ using a microplate reader (POLARstar OPTIMA, BMG, Germany). Triplicate assays were conducted for all conditions.

\section{Caspase-3 protease activity}

$\mathrm{RAW}_{264.7}$ cells and BMDM were cultured in six-well plates at a density of $0.3 \times 10^{6}$ cells/well for $48 \mathrm{hr}$. After treatments, trypsin-detached $\mathrm{RAW}_{264.7}$ cells and scraped BMDM were lysed and assayed for caspase- 3 activity as described previously [20].

\section{Flow cytometry analysis}

Apoptotic cells were quantitated by staining with annexin V-PE and 7-AAD, as specified by the manufacturer (BD Biosciences). Flow cytometry was performed on populations of 5000-10,000 cells (Becton Dickinson FACSCalibur, Sydney, NSW, Australia), with fluorescence of annexin V-PE and 7-AAD measured with a $585 / 42 \mathrm{~nm}$ bandpass filter (FL2 channel) and a $670 \mathrm{~nm}$ longpass filter (FL3 channel), respectively. Data are expressed as percentages of apoptotic cells, as defined by annexin-V-PE positivity and 7-AAD negativity.

\section{Cell cycle analysis}

RAW $_{264.7}$ cells and BMDM $\left(0.25 \times 10^{6} /\right.$ well of a 12 -well plate) were collected and washed in cold Dulbecco's Phosphate Buffered Saline (DPBS) before being fixed with $70 \%$ ethanol at $-20^{\circ} \mathrm{C}$. After $24 \mathrm{hr}$, cells were centrifuged at $500 \times g$ for 10 minutes at $4{ }^{\circ} \mathrm{C}$ and resuspended in $500 \mu \mathrm{L}$ of staining buffer $(50 \mu \mathrm{g} / \mathrm{mL}$ propidium iodide and $25 \mu \mathrm{g} / \mathrm{mL}$ RNase in $0.1 \%$ Triton $\mathrm{X}-100$ ). After incubating at $37^{\circ} \mathrm{C}$ for 30 minutes, cells were analysed on a FACSCalibur flow cytometer (Becton Dickinson) using a doublet discrimination protocol.

\section{Western blot analysis}

RAW $_{264.7}$ cells and BMDM $\left(1 \times 10^{6}\right.$ per treatment $)$ were washed with ice-cold DPBS and lysed in RIPA buffer (50 mM Tris, pH 7.5, containing $150 \mathrm{mM} \mathrm{NaCl}$, 1\% IGEPAL, 1\% sodium deoxycholate, $0.1 \%$ SDS and $10 \mathrm{mM}$ EDTA) supplemented with $1 \mathrm{X}$ complete protease inhibitors (Roche Applied Science, Sydney, NSW, Australia). A total of $20 \mu \mathrm{g}$ of total protein was separated by SDSPAGE and transferred to Hybond-P PVDF membranes (Amersham Biosciences). Membranes were blocked in 1\% BSA/5\% non-fat milk in TTBS (10 mM Tris, $\mathrm{pH} 7.6$, $150 \mathrm{mM} \mathrm{NaCl}, 0.1 \%$ Tween 20) for one hour at room temperature, before being probed with specific antibodies to phospho-I $\kappa \mathrm{B} \alpha$ (1:1000 dilution), $\mathrm{I} \kappa \mathrm{B} \alpha(1: 2,000)$ or $\beta$-actin $(1: 8,000)$. Horseradish peroxidase-conjugated antirabbit and anti-mouse were used at 1:8,000 and 1:20,000 dilutions, respectively. All antibodies were prepared in SignalBoost Immunoreaction Enhancer (Calbiochem, Darmstadt, Germany) and applied for one hour at room temperature. Blots were revealed with enhanced chemiluminescence (ECL) reagents (Amersham Biosciences).

\section{Electrophoretic Mobility Shift Assay (EMSA)}

EMSA was performed on nuclear extracts from RAW 264.7 cells $\left(8 \times 10^{6}\right.$ per treatment $)$ that were treated with $10 \mathrm{ng} /$ $\mathrm{mL}$ TNF- $\alpha$ for up to one hour, according to previously described protocols [21]. A double-stranded NF- $\kappa \mathrm{B}$ consensus oligonucleotide probe 5'-GGGCATGGGAA TTTCCAACTC-3' (0.25 pmol) with 5'-G overhangs was filled in with labeled $\left(\alpha-{ }^{32} \mathrm{P}\right) \mathrm{dCTP}$ (Amersham Pharmacia Biotech, Buckinghamshire, England) using the Klenow fragment of E. coli DNA polymerase I (Promega, Madison, Wisconsin, USA). This DNA probe was incubated with $3 \mu \mathrm{g}$ of nuclear proteins for 10 minutes at room temperature. Where indicated, antibodies $(1 \mu \mathrm{g})$ to specific NF- $\kappa \mathrm{B}$ factors or unlabelled oligonucleotide probes at 100-fold molar excess were also included for supershift EMSA and competition experiments, respectively. Samples were loaded onto a $4 \%$ polyacrylamide gel, containing $0.25 \mathrm{X}$ TrisBorate-EDTA buffer, which had been pre-run for two hours in the same buffer. After separation, gels were exposed to Cronex X-ray film, using a single intensifying screen.

\section{Transient transfection of $\mathrm{RAW}_{264.7}$ cells and BMDM with an $\mathrm{NF}-\kappa \mathrm{B}$ reporter plasmid}

$\mathrm{RAW}_{264.7}$ cells $\left(1 \times 10^{7}\right)$ were transiently transfected with $0.5 \mu \mathrm{g}$ of $\mathrm{pNF} \kappa \mathrm{B}-\mathrm{TA}-\mathrm{Luc}$ (Mercury ${ }^{\mathrm{TM}}$ Pathway profiling system, BD Biosciences) by the DEAE-dextran procedure, as previously described [21]. Transfected cells were resuspended in DMEM-FCS and distributed into a 24-well culture plate at a density of $3.3 \times 10^{5}$ cells/well. Cells were rested for $48 \mathrm{hr}$ before experimentation. Firefly luciferase expression in transfected $\mathrm{RAW}_{264.7}$ cells was measured using the Promega Luciferase Assay System, according to the manufacturer's instructions. Promoter activity was quantified by measuring light production in a multifunctional microplate reader (POLARstar OPTIMA, BMG, Germany), and presented as relative light units (RLU).

BMDM were transfected with Lipofectamine ${ }^{\mathrm{TM}}$ and Plus reagents (Invitrogen) according to manufacturer's instructions. Briefly, for each 24-well, $1 \mu \mathrm{g}$ pNF- $\kappa \mathrm{B}-\mathrm{TA}-$ Luc was combined with $0.5 \mu \mathrm{L}$ Plus reagent and $2 \mu \mathrm{L}$ Lipofectamine $^{\mathrm{TM}}$ in antibiotic-free medium. A total of $1.5 \times 10^{5}$ cells/well was added to the transfection mixture and plated in M-CSF-containing DMEM-FCS. After four to six hours of incubation at $37^{\circ} \mathrm{C}$, wells were replaced with fresh growth medium. Luciferase expression was measured at least $48 \mathrm{hr}$ after transfection.

\section{Statistical analysis}

Statistical significance $(P<0.05)$ between groups of experimental data was assessed using paired Student's $t$-tests. 


\section{Results}

TNF- $\alpha$ protects primary macrophages and a macrophage cell line from MTX-induced apoptosis

$\mathrm{M}$-CSF is the primary growth, differentiation and survival factor for macrophages under physiological conditions. Serum concentrations of M-CSF are elevated to approximately $0.6 \mathrm{ng} / \mathrm{ml}$ in patients with RA [22], but concentrations in synovium are unknown. In vitro, a concentration of $30 \mathrm{ng} / \mathrm{ml}$ was optimal for sustaining the growth and survival of bone marrow-derived macrophages (BMDM) of C57BL/6 mice (results not shown). In the presence of $30 \mathrm{ng} / \mathrm{mL} \mathrm{M-CSF}$, exposure to $10 \mu \mathrm{M}$ MTX for $24 \mathrm{hr}$ caused an approximately $25 \%$ loss of cell numbers in BMDM cultures (Figure 1A). This was related to increased apoptosis, as estimated by caspase-3 activity (Figure 1B), annexin-V binding (early apoptosis; Figure 1B) and increased sub- $G_{0}$ (apoptotic) fraction on flow cytometric cell cycle analysis (Table 1). The proportion of cells in S-phase also increased with MTX, consistent with its known action on completing DNA synthesis [23] (Table 1).

Caspase- 3 activation was evident at concentrations as low as $0.1 \mu \mathrm{M}$ MTX in BMDM, with activity increasing dose-dependently up to $10 \mu \mathrm{M}$ (Figure 1C). MTX, therefore, induces macrophage apoptosis at levels usually attained in treated human RA patients [24]. This was replicated in the murine $\mathrm{RAW}_{264.7}$ macrophage cell line (Figure 1E). RAW 264.7 macrophages do not require exogenous M-CSF to proliferate, having gained growth signaling through introduction of the Abelson leukaemia virus [25]. They have been previously found to model primary macrophage apoptosis response [26]. A concentration of $10 \mu \mathrm{M}$ MTX was used in subsequent experiments.

TNF- $\alpha$ could also maintain the viability of macrophages exposed to $10 \mu \mathrm{M}$ MTX. TNF- $\alpha$, when introduced three hours before MTX, completely prevented the loss of cell numbers in primary BMDM cultures exposed to MTX (Figure 1A). TNF- $\alpha$ also almost completely inhibited MTX-induced caspase- 3 activation (Figure 1B) and annexin-V binding (Figure 1B) and significantly suppressed the sub- $G_{0}$ (apoptotic) fraction on flow cytometric cell cycle analysis of MTX-exposed BMDM (Table 1). TNF- $\alpha$ did not reverse the MTXinduced increase in cells in S-phase. TNF- $\alpha$, therefore, protected from MTX-induced cell loss by countering apoptosis, not through any action on cell proliferation. TNF- $\alpha$ also reduced the sub- $G_{0}$ population of M-CSFdeprived BMDM, without restoring $S$ phase progression (Table 1). It is notable that TNF- $\alpha$ was protective even in the presence of M-CSF concentrations that are optimal for apoptosis prevention, suggesting distinct pathways for apoptosis protection. Further increases in $\mathrm{M}-\mathrm{CSF}$ concentration in culture, up to $120 \mathrm{ng} / \mathrm{mL}$, failed to substitute for the anti-apoptotic action of TNF$\alpha$ (results not shown). This suggested an action that was independent of M-CSF intracellular signaling and removed the possibility that TNF- $\alpha$ was acting through autocrine induction of M-CSF secretion. At least three hours of pre-exposure to TNF- $\alpha$ was required for optimal protection from MTX-induced apoptosis (results not shown).

TNF- $\alpha$ provided comparable protection from MTXinduced apoptosis in the $\mathrm{RAW}_{264.7}$ macrophage cell line. TNF- $\alpha$ exposure significantly $(P<0.05)$ suppressed spontaneous apoptosis of $\mathrm{RAW}_{264.7}$ cells as measured by caspase- 3 activity and annexin- $\mathrm{V}$ binding (Figure 1D). $\mathrm{RAW}_{264.7}$ cells shared the susceptibility of primary macrophages to MTX, demonstrating enhanced caspase3 activity and annexin- $\mathrm{V}$ binding after six hours of exposure (Figure 1D). This increase was markedly suppressed when TNF- $\alpha$ was added three hours before MTX (Figure 1D). Thus, the anti-apoptotic effect of TNF- $\alpha$ is replicated in $\mathrm{RAW}_{264.7}$ cells, allowing use of this cell line for studying the phenomenon.

\section{TNF- $\alpha$ protection from apoptosis is mediated through} TNF-R1 (p55), not TNF-R2 (p75) receptor activation

Monocytes/macrophages express both TNF-R1 and TNF-R2 [8]. To determine the receptor subtype(s) that mediated the survival effect of TNF- $\alpha$, we exploited the species specificity of TNF- $\alpha$ action. Murine TNF- $\alpha$ (mTNF- $\alpha$ ) activates both TNF-R1 and TNF-R2 on murine macrophages, while human TNF- $\alpha$ (hTNF- $\alpha$ ) activates TNF-R1 only, thereby providing a means to distinguish effects that are mediated through different receptors [27]. mTNF- $\alpha$ and hTNF- $\alpha$ provided comparable protection from MTX-induced caspase-3 activation (Figure 2, $P>0.05$ ), indicating that protection is mediated through TNF-R1, and does not require TNFR2 signaling.

\section{NF- $\kappa \mathrm{B}$ is required for the survival effect of TNF- $\alpha$ in macrophages}

TNF-R1 ligation activates several pro-survival pathways via its association with TRAF2 (TNFR-Associated Factor 2), RIP (Receptor-Interacting Protein) c-Src and Jak2. These include the NF- $\kappa$ B pathway, Phosphatidylinositol3-Kinase/Protein Kinase B (PI3K/AKT) and MitogenActivated Protein Kinase pathways [28,29]. Constitutive NF $-\kappa \mathrm{B}$ activity is critical to macrophage survival [26]. Therefore, we next examined the kinetics of NF- $\kappa \mathrm{B}$ activation in TNF- $\alpha$-stimulated macrophages and investigated whether NF- $\kappa \mathrm{B}$ activity was required for the anti-apoptotic effect of TNF- $\alpha$.

Proteosomal degradation of the NF- $\kappa \mathrm{B}$ inhibitory protein, $\mathrm{I} \kappa \mathrm{B} \alpha$, is an early indicator of activation in the canonical NF- $\kappa$ B pathway [30]. TNF- $\alpha(10 \mathrm{ng} / \mathrm{mL})$ 
A

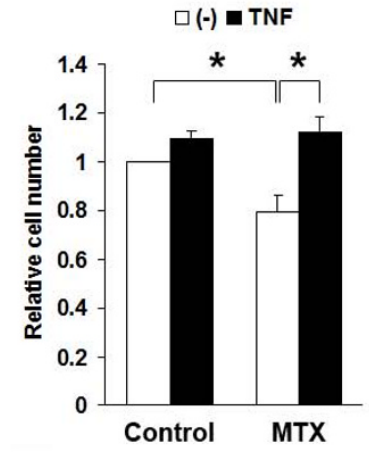

B

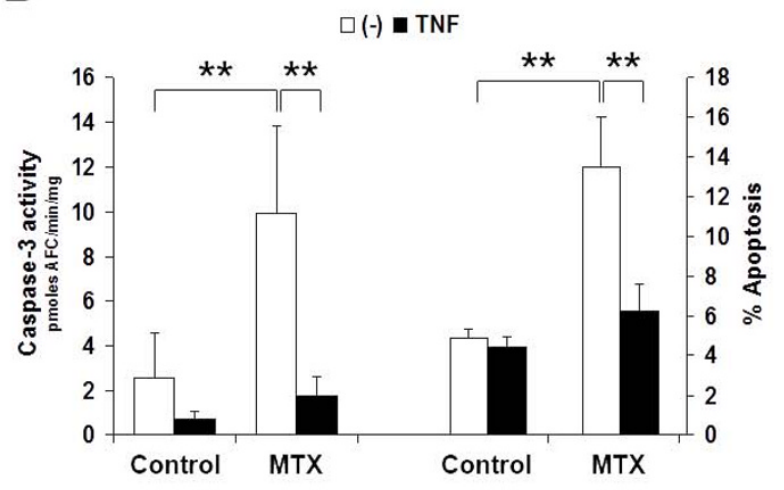

D

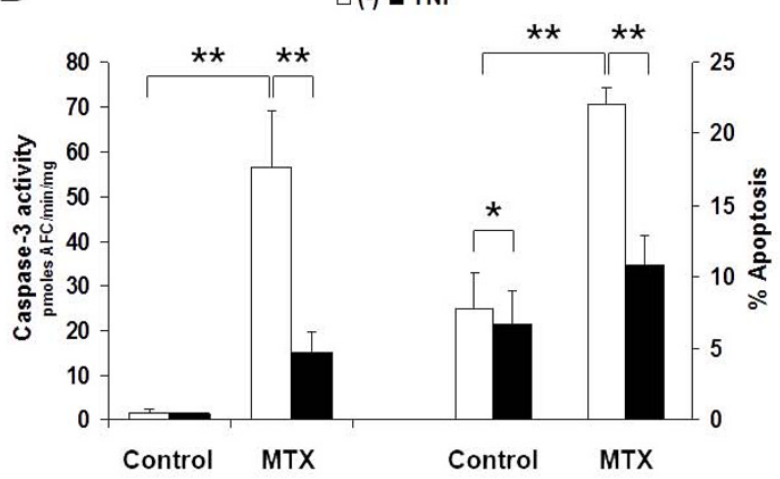

C

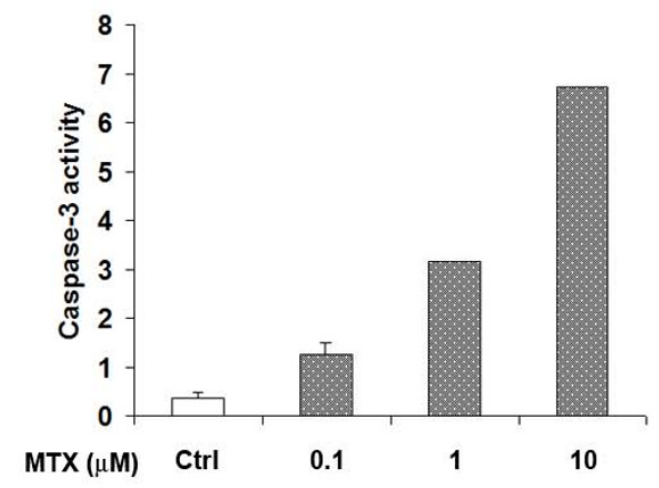

E

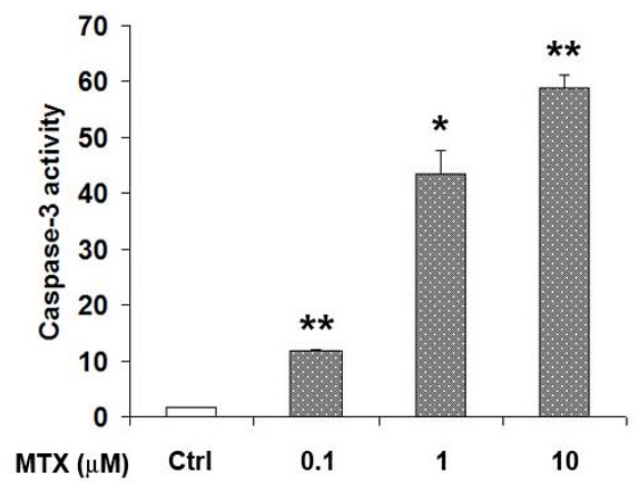

Figure 1 TNF-a antagonises MTX-induced apoptosis in macrophages, independent of M-CSF action. A. Exposure of primary BMDM to $10 \mathrm{mM}$ MTX for $24 \mathrm{hr}$ in the presence of $30 \mathrm{ng} / \mathrm{mL}$ M-CSF resulted in loss of approximately $25 \%$ of cells. This could be entirely prevented by introducing TNF-a three hours before MTX. Cell viability was assessed by the MTT reduction assay. Shown are mean \pm SEM of normalised data from three independent experiments. B and D, TNF-a suppresses caspase-3 activation (left axis) and annexin-V binding (right axis) in MTXexposed primary BMDM (B) and RAW 264.7 cells (D). MTX was added three hours after TNF-a treatment, and caspase-3 activity or annexin-V binding was measured after $24 \mathrm{hr}$ for BMDM and $6 \mathrm{hr}$ for RAW 264.7 cells. Data are mean \pm SEM of at least four independent experiments in each case. $\mathbf{C}$ and $\mathbf{E}$, MTX dose-dependently increases apoptosis in BMDM (C) and RAW 264.7 cells $(\mathbf{E}) .^{*}=P<0.05 ;{ }^{* *}=P<0.01$.

addition in $\mathrm{RAW}_{264.7}$ cells induced the degradation of $\mathrm{I} \kappa \mathrm{B} \alpha$ within 15 minutes (Figure $3 \mathrm{~A}, P<0.05$ ). This corresponded to the appearance of DNA-binding NF- $\kappa \mathrm{B}$ in the nucleus, with activity peaking at 30 minutes before returning to baseline levels by one hour (Figure $3 \mathrm{~B}$ ).
Supershift analyses with specific antibodies to RelA, NF- $\kappa B_{1}$, c-Rel and Rel-B identified RelA (p65) and $\mathrm{NF}-\kappa \mathrm{B}_{1}$ (p50) as the main components of the NF- $\kappa \mathrm{B}$ complex induced by TNF- $\alpha$ (Figure 3B). A light c-Rel supershifted band was also detected (Figure $3 \mathrm{~B}$ ). I $\kappa \mathrm{B} \alpha$ 
Table 1 Cell cycle analysis of BMDM treated with TNF- $\alpha$ or its control, followed by MTX exposure for $24 \mathrm{hr}$ or M-CSF withdrawal for 48 hr* $^{*}$

\begin{tabular}{lcccc}
\hline \multicolumn{5}{c}{ Cell cycle distribution (\% of cells) } \\
& sub G0 & G0/G1 & s & G2/M \\
\hline Control & $3.5 \pm 0.5$ & $78.6 \pm 2.9$ & $6.0 \pm 1.0$ & $10.7 \pm 2.7$ \\
MTX $(10 \mu M)$ & $7.5 \pm 1.0^{\mathrm{a}}$ & $62.7 \pm 2.2^{\mathrm{a}}$ & $16.0 \pm 1.2^{\mathrm{a}}$ & $12.0 \pm 1.2$ \\
TNF- $\alpha(10 \mathrm{ng} / \mathrm{mL})$ & $3.6 \pm 0.4$ & $77.0 \pm 2.2$ & $7.5 \pm 1.7$ & $10.7 \pm 2.0$ \\
TNF- $\alpha+$ MTX & $5.8 \pm 0.8^{\mathrm{b}}$ & $65.7 \pm 4.8$ & $13.8 \pm 3.2$ & $13.1 \pm 2.6$ \\
& & & & \\
M-CSF (30 ng/mL) & $1.5 \pm 0.4$ & $74.2 \pm 2.6$ & $8.4 \pm 1.9$ & $13.9 \pm 2.2$ \\
- M-CSF & $15.4 \pm 4.1^{\mathrm{a}}$ & $74.7 \pm 5.1$ & $2.8 \pm 0.7^{\mathrm{a}}$ & $5.5 \pm 0.9^{\mathrm{a}}$ \\
M-CSF + TNF- $\alpha$ & $1.5 \pm 0.2$ & $71.8 \pm 1.9$ & $9.3 \pm 1.3$ & $15.3 \pm 2.7$ \\
- M-CSF + TNF- $\alpha$ & $4.4 \pm 2.3^{\mathrm{b}}$ & $82.3 \pm 3.7^{\mathrm{b}}$ & $1.9 \pm 0.4$ & $9.7 \pm 2.7$ \\
\hline
\end{tabular}

*Results are mean \pm SEM of at least three independent experiments in each case. ${ }^{\mathrm{a}} P<0.05$ compared to controls. ${ }^{\mathrm{b}} P<0.05$ compared to MTX alone or no M-CSF.

BMDM, bone marrow-derived macrophages; M-CSF, macrophage colony stimulating factor; MTX, methotrexate; TNF- $\alpha$, tumor necrosis factor-alpha.

levels recovered by one hour (Figure 3A). The IKBA gene is also NF- $\kappa \mathrm{B}$-responsive, so early recovery of $\mathrm{I} \kappa \mathrm{B} \alpha$ levels indicates functional NF- $\kappa \mathrm{B}$ signaling [30]. Lastly, TNF- $\alpha$ stimulation of $\mathrm{RAW}_{264.7}$ cells transiently expressing a NF- $\kappa$ B-responsive reporter construct showed that NF- $\kappa$ B transcriptional activity was enhanced in a time-dependent
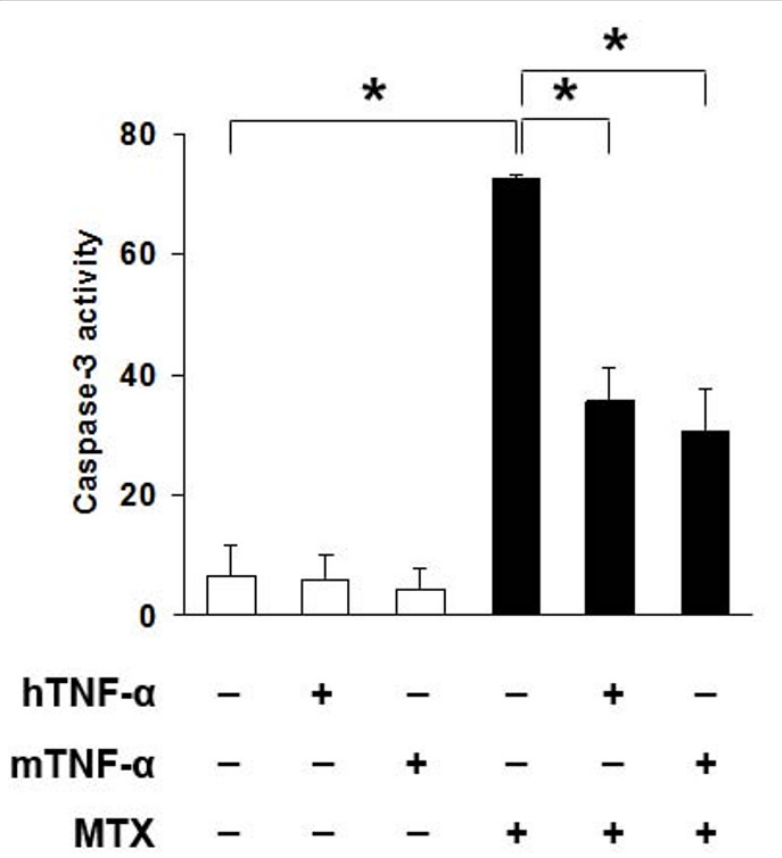

Figure 2 Human (h) and murine (m) TNF-a confer comparable protection against apoptosis in $\mathrm{RAW}_{264.7}$ cells exposed to 10 mM MTX. Caspase-3 activity was measured after six hours with MTX, without TNF-a, or pre-treated with $10 \mathrm{ng} / \mathrm{mL}$ mTNF-a or hTNF-a for three hours. Shown are mean \pm SEM of three independent experiments. ${ }^{*}=P<0.05$. manner (Figure 3C). These results confirm that TNF- $\alpha$ is a rapid activator of NF- $\kappa$ B function in macrophages.

To investigate whether NF- $\kappa \mathrm{B}$ activity is essential for TNF- $\alpha$ activity against MTX-induced apoptosis, the sesquiterpene lactone parthenolide (PAR) and BAY11-7085 (BAY) were used to specifically prevent NF- $\kappa$ B signaling $[19,31]$. PAR and BAY pre-treatment for 30 minutes abolished both constitutive and TNF- $\alpha$-stimulated NF- $\kappa \mathrm{B}$ transcriptional activity (Figure $4 \mathrm{~A}$ ). They also completely prevented TNF- $\alpha$ from rescuing $\mathrm{RAW}_{264.7}$ cells (Figure 4B,C) and primary macrophages (Figure 4D-F) from MTX-induced apoptosis and caspase- 3 activation. These findings indicate that NF- $\kappa \mathrm{B}$ activation is required for TNF- $\alpha$ protection against apoptosis induced by MTX. Notably, TNF- $\alpha$ became proapoptotic, rather than anti-apoptotic when NF- $\kappa \mathrm{B}$ signaling was blocked, when estimated by either annexin- $\mathrm{V}$ binding $(P<0.05)$ or caspase-3 activity $(P<0.05)$.

The involvement of PI3K/AKT, ERK, JNK and p38 MAP kinases was also explored using their specific inhibitors, but they were found to be dispensable for TNF- $\alpha$-induced survival of macrophages, as assessed by annexin- $\mathrm{V}$ staining and caspase- 3 activity (results not shown).

\section{Autocrine TNF- $\alpha$ signaling is not required for basal} survival of M-CSF-maintained macrophages

Macrophages are also sources of TNF- $\alpha$, raising the possibility that constitutive NF- $\kappa \mathrm{B}$ activity (and thus survival) depended on autocrine TNF- $\alpha$ stimulation. We, therefore, treated BMDM cultures with etanercept, a chimeric protein comprising Fc domains of human IgG $_{1}$ and TNF- $\alpha$-binding domains of the Type 2 TNF receptor, which neutralises both murine and human TNF- $\alpha$ [32]. An irrelevant human myeloma-derived $\mathrm{IgG}_{1}$ served as a control. Etanercept, however, did not increase caspase- 3 activation, indicating that autocrine TNF- $\alpha$ stimulation was not important for survival of macrophages cultured with optimal concentrations of M-CSF (results not shown).

RANKL, a weak activator of NF- $\kappa$ B in macrophages, does not protect from MTX-induced apoptosis

The observation that TNF- $\alpha$ protected macrophages from MTX-induced apoptosis led us to question whether other cytokines present in rheumatoid synovium or erosions may also protect through NF- $\kappa$ B induction. Receptor Activator of NF- $\kappa$ B Ligand (RANKL) circulates at elevated concentration in RA and is demonstrable in rheumatoid synovium and erosions [33]. It is required for osteoclast formation from monocyte/macrophage precursors. Unlike TNF- $\alpha$, however, RANKL did not suppress caspase- 3 activation in MTX-exposed primary macrophage cultures at concentrations up to $400 \mathrm{ng} / \mathrm{mL}$ (Figure $5 \mathrm{~A}$ ). A dose of $200 \mathrm{ng} / \mathrm{mL}$ of RANKL is sufficient to elicit classical 
A
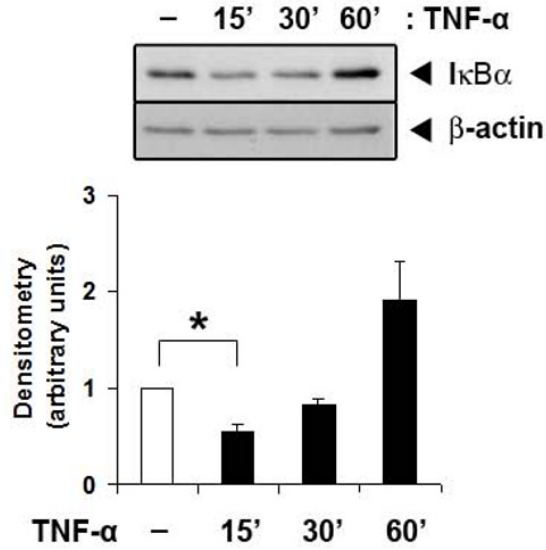

B
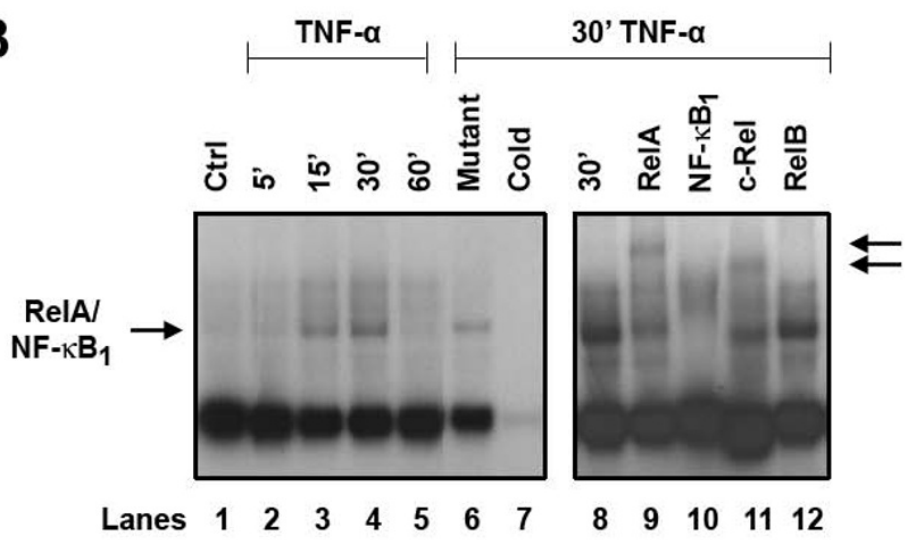

C

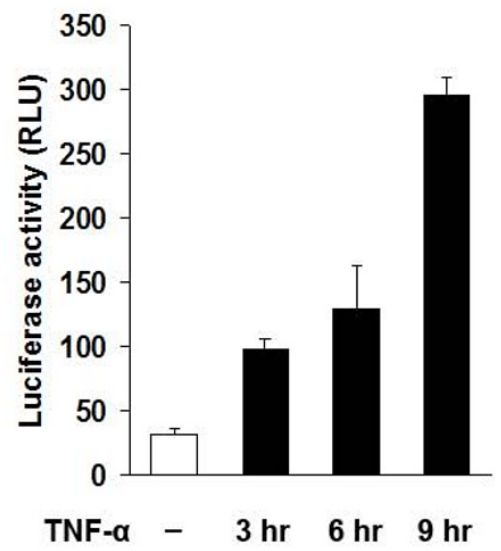

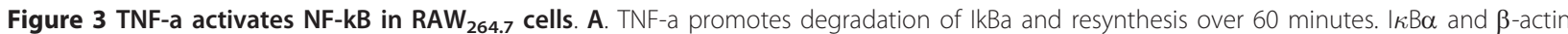
protein levels were assessed by Western blot analysis and quantified by densitometry (lower panel). Densitometry data show $I_{\kappa B} \alpha$ levels that were corrected by $\beta$-actin and represent normalised data from four independent experiments. ${ }^{*}=P<0.05$. B. EMSA for NF-kB proteins in nuclear extracts of RAW 264.7 cells over six hours of TNF-a exposure. The arrow on the left indicates the position of the RelA/NF- $\mathrm{B}_{1}$ heterodimer. Competition for binding by an unlabeled specific oligonucleotide (lane 7) but not by an irrelevant sequence at 100-fold molar excess (lane 6) confirmed specificity of DNA binding. Supershift analyses with specific antibodies to RelA, NF-kB 1 (p50), c-Rel and RelB (lanes 9, 10, 11 and 12, respectively, of the right panel) confirmed the identities of RelA and NF-kB$B_{1}$ in the complex with a lighter supershift c-Rel band. Arrows on the right indicate the locations of supershifted bands. The figure is representative of two independent experiments. C. TNF-a (10 ng/ml) induces NF-kB activity, as estimated by luciferase activity in RAW $_{264.7}$ cells that had been transiently transfected with the pNF-kB-TA-Luc reporter. Results are representative of three independent experiments. 
A

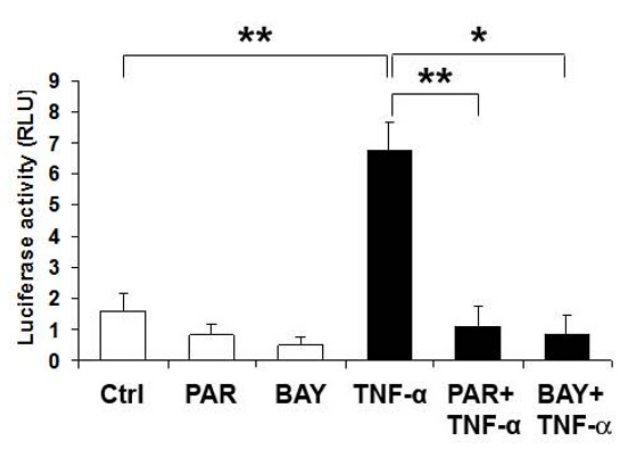

C

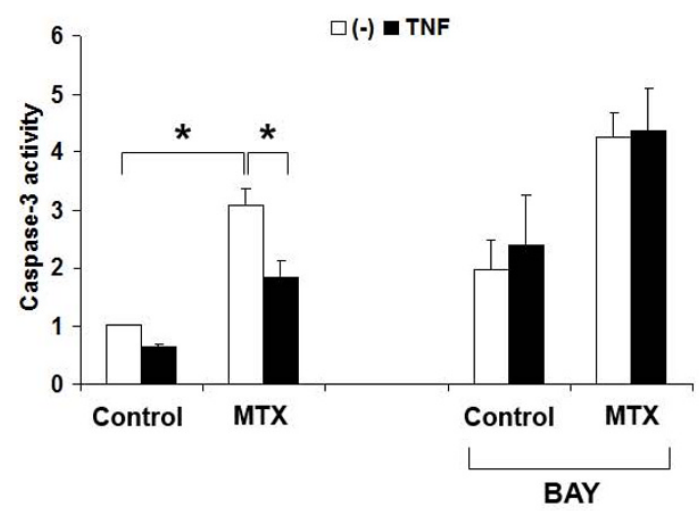

E

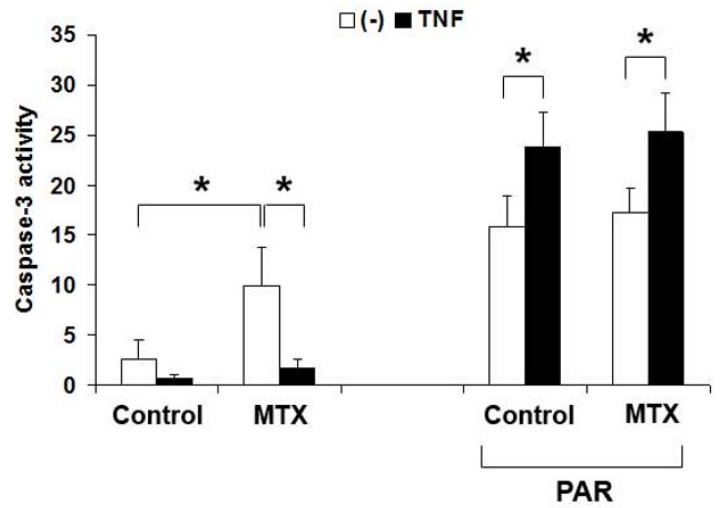

B

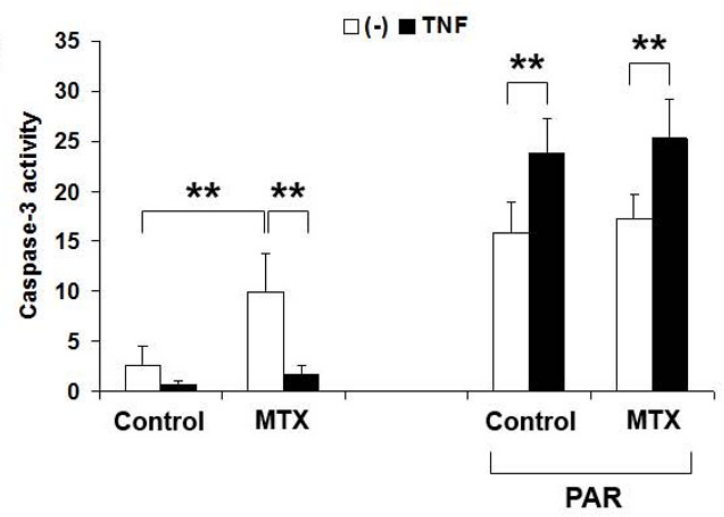

D

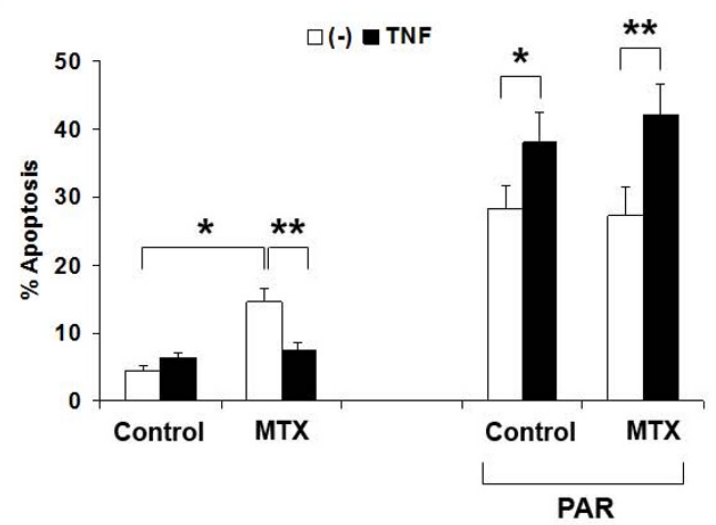

$\mathbf{F}$

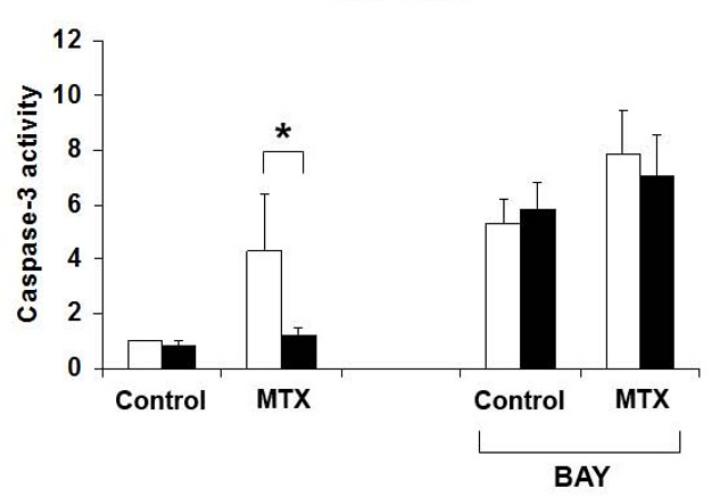

Figure 4 TNF-a must activate NF-kB signaling to protect macrophages from MTX-induced apoptosis. A. PAR and BAY (10 $\mu$ M) prevent TNF-a-induced NF-kB activity in RAW 264.7 cells, as measured by activity of the pNF-kB-TA-Luc reporter. Inhibitors were introduced 30 minutes before TNF-a and luciferase activity was measured nine hours later. Results are mean \pm SEM of at least four independent experiments. B-F. PAR and BAY (10 mM or 7.5 mM) prevent TNF-a from rescuing MTX-treated RAW 264.7 cells (B and C) and BMDM (D-F) from apoptosis. Cells were exposed to PAR ( $B, D$, and E) or BAY (C and F) for 30 minutes before TNF-a stimulation for three hours, after which MTX was introduced. Annexin- $V$ binding and/or caspase-3 activity was measured 6 hours later in RAW 264.7 cells and 24 hours later in BMDM. Results are mean \pm SEM of at least three independent experiments in each case. Normalised data are shown for BAY experiments. ${ }^{*}=P<0.05$; ${ }^{* *}=P<0.01$.

osteoclastogenesis in our hands [34], so was used for other experiments. Comparing effects on NF- $\kappa \mathrm{B}$ activation, we found that RANKL (six hours) stimulated an approximately three-fold increase in NF- $\kappa$ B-luciferase reporter expression in transfected BMDM, well short of the approximately 22 -fold increase with TNF- $\alpha$ (Figure 5B). Western blot analyses also indicated weaker phosphorylation and degradation of $\mathrm{I} \kappa \mathrm{B} \alpha$ after RANKL treatment, compared to TNF- $\alpha$ (Figure $5 \mathrm{C}$ ). Therefore, RANKL does not protect differentiated primary macrophages from MTX, possibly due to insufficient activation of $\mathrm{NF}-\kappa \mathrm{B}$. 


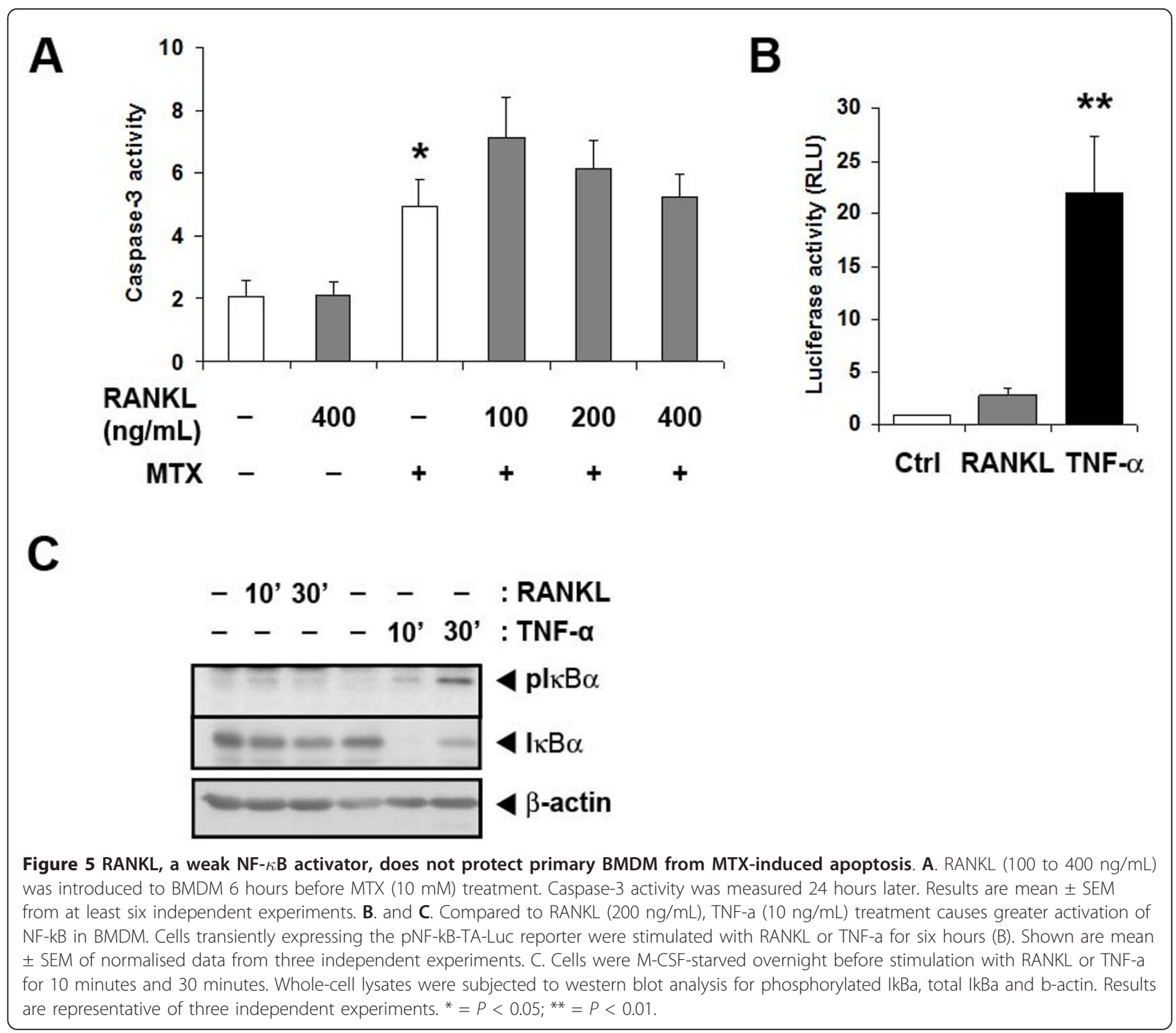

MTX itself does not induce apoptosis through NF- $\kappa$ B suppression

The observation that NF- $\kappa \mathrm{B}$ induction countered the apoptotic action of MTX led us to test whether MTX itself acted through inhibiting NF- $\kappa \mathrm{B}$. This has been previously observed in Jurkat T-cells and in the poorly differentiated myelo-monocytic U937 cell line [35]. However, MTX, at concentrations sufficient to induce apoptosis, failed to suppress either basal or TNF- $\alpha$ induced NF- $\kappa \mathrm{B}$ activity in $\mathrm{RAW}_{264.7}$ cells transiently transfected with a specific NF- $\kappa \mathrm{B}$ reporter construct (pNF- $\kappa \mathrm{B}-\mathrm{TA}-\mathrm{Luc}$ ) (Figure 6A). In BMDM, it also failed to prevent the TNF- $\alpha$-stimulated phosphorylation of $\mathrm{I} \kappa \mathrm{B} \alpha$, an essential step in $\mathrm{I} \kappa \mathrm{B} \alpha$ degradation and RelA/ $\mathrm{NF}-\kappa \mathrm{B}_{1}$ complex release (Figure $6 \mathrm{~B}$ ). MTX, therefore, does not exert its apoptotic actions through NF- $\kappa \mathrm{B}$ suppression.
Anti-inflammatory actions of MTX on macrophages have been attributed to enhanced extracellular adenosine generation. However, neither adenosine itself (Figure $6 \mathrm{C}$ ), or the pan-adenosine receptor agonist NECA (Figure 6D), affected caspase-3 activity. Thus, adenosine accumulation alone is not a sufficient explanation for MTX-induced macrophage apoptosis.

\section{Discussion}

TNF- $\alpha$ protects macrophages from apoptosis induced by MTX. This offers an explanation for the clinical observation that anti-TNF- $\alpha$ treatments cause apoptosis of monocyte/macrophage lineage cells in peripheral blood and synovium of patients with RA [4], in a study where most participants were also taking MTX. The survival signal from TNF- $\alpha$ is transduced through TNF-R1 and the canonical NF- $\kappa$ B pathway. M-CSF, which directs 


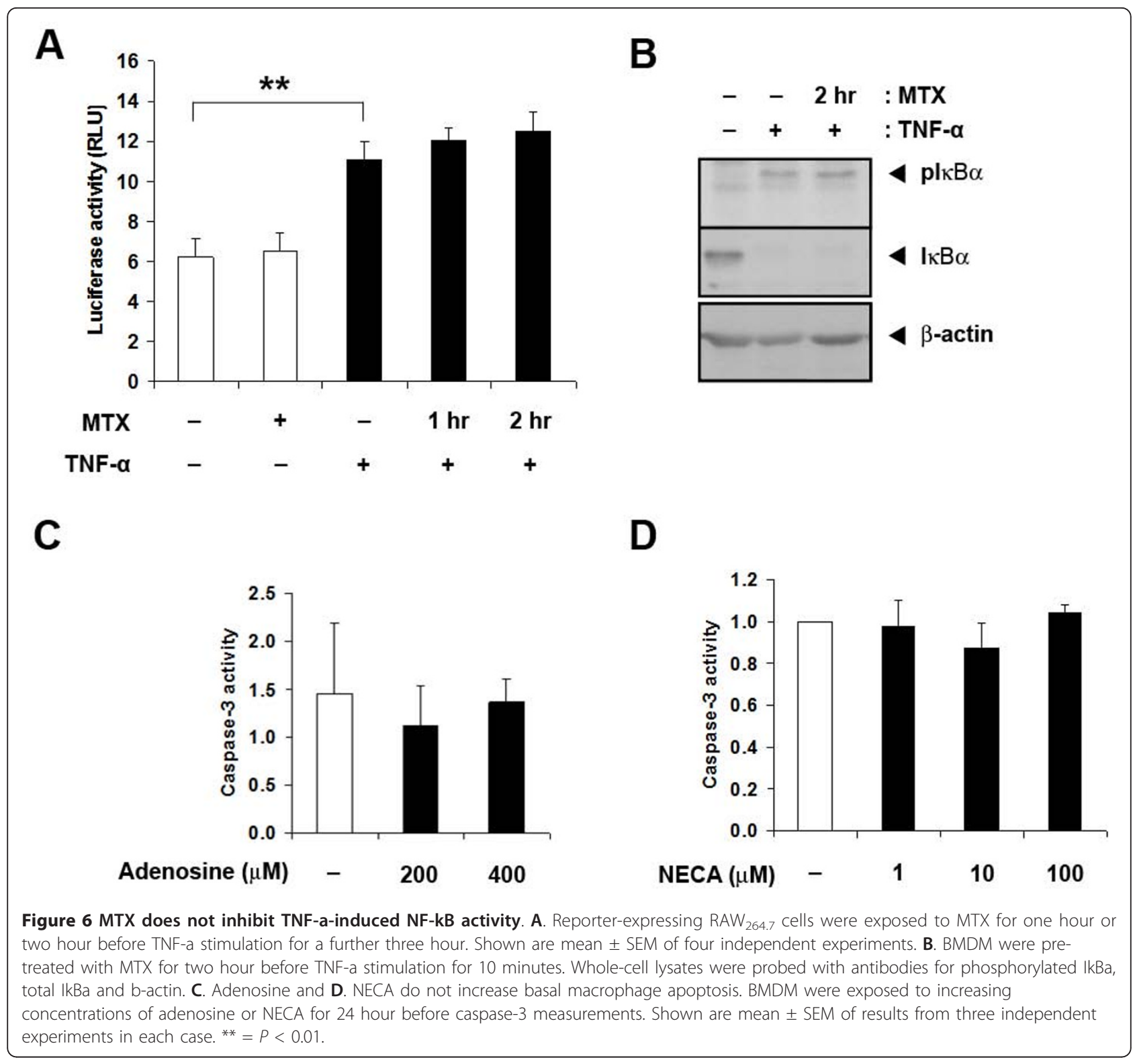

macrophage differentiation, growth and survival, but does not activate NF- $\kappa \mathrm{B}$ signaling, cannot substitute for TNF- $\alpha$. This is notable, because M-CSF is present in peripheral blood and synovial fluid in RA [22], and might have been expected to render anti-apoptotic effects of TNF- $\alpha$ redundant. M-CSF signals for growth and survival primarily through the PI3K/AKT pathway.

TNF- $\alpha$ can activate both pro-apoptotic and anti-apoptotic pathways, with outcomes that differ between cell types and conditions. The importance of NF- $\kappa \mathrm{B}$ signaling in survival is highlighted by the outcomes of PAR and BAY exposure, which converted TNF- $\alpha$ from a dominantly pro-survival signal to an apoptotic signal. NF- $\kappa$ B-regulated proteins that have been linked to inhibition of apoptotic signaling include TRAF-1, TRAF-2, CIAP-1, CIAP-2, XIAP, FLIP, A20,
GADD45 3 , the antioxidant Mn-SOD, and anti-apoptotic members of the Bcl-2 family, such as A1 and Bcl-xL [36].

The canonical NF- $\kappa \mathrm{B}$ pathway is activated in macrophages of rheumatoid synovium [12], consistent with a role in maintaining cell survival in untreated patients $[10,11]$. Other products of the inflamed synovium, including IL-1, RANKL, GM-CSF, VEGF, PDGF and leukotrienes [37] can promote NF- $\kappa \mathrm{B}$ signaling in responsive cells and may contribute, with TNF- $\alpha$, to NF- $\kappa \mathrm{B}$ activation in macrophages of rheumatoid synovium. However, the experiments with RANKL indicated that not all NF- $\kappa \mathrm{B}$ activators protect from apoptosis. RANKL failed to protect primary murine macrophages from MTX-induced apoptosis, even at concentrations that promote osteoclastogenesis in our hands [34] and 
which exceed the concentrations reported in rheumatoid synovial fluid [38]. The difference may arise because RANKL activates NF- $\kappa$ B less intensely, or because of differences in other pathways recruited by TNF-R1 and RANK. Finding that RANKL is not a survival factor for macrophages mirrors findings with osteoclast precursors, where RANKL promotes activation and differentiation, but not survival [39]. The mature osteoclast, however, is protected from apoptosis by RANKL with mixed reports of NF- $\kappa \mathrm{B}$ involvement [40]. The finding that RANKLinduced NF- $\kappa \mathrm{B}$ activation is insufficient to protect primary macrophages from apoptosis is also in accord with the conclusion from clinical studies, that RANKL is not an important driver of synovial inflammation in RA, even though it is critical for erosion formation [41].

MTX has been reported to suppress NF- $\kappa \mathrm{B}$ activity in a different cell context [35]. However, NF- $\kappa$ B suppression could not be demonstrated in MTX-exposed macrophages, so cannot be the mechanism of MTXinduced macrophage apoptosis. MTX anti-inflammatory response has also been linked with the extracellular accumulation of adenosine. Adenosine is reported to promote apoptosis of colon cancer cells in vitro [42], but we could find no evidence that adenosine alone causes apoptosis in macrophages. The experiments could not disprove a permissive role for adenosine. The experiments do, however, prove that MTX and TNF- $\alpha$ do not just act conversely on NF- $\kappa \mathrm{B}$ signaling. MTX has many potentially apoptotic actions $[3,13,15]$ and NF- $\kappa$ B has many anti-apoptotic actions [36]. It, therefore, seems more likely that the fate of TNF- $\alpha$ and MTXexposed macrophages is decided by the late effectors of apoptosis signaling, particularly at mitochondrial steps, that integrate and balance multiple converging inputs [43]. This requires better definition.

Macrophage NF- $\kappa \mathrm{B}$ signaling is an attractive therapeutic target in RA because of roles in inflammation, differentiation and survival. However, NF- $\kappa \mathrm{B}$ pathways are employed in diverse tissues, with broad biological consequences. Anti-TNF- $\alpha$ treatments suppress NF- $\kappa$ B activity in circumstances where it is promoted by TNF- $\alpha$, such as in the synovial macrophage. Currently available NF- $\kappa$ B-suppressing small molecules, however, lack such cellular specificity. Glucocorticoids suppress macrophage NF- $\kappa \mathrm{B}$ activity, but with poor specificity [21]. The proteosomal inhibitor, bortezomib, suppresses NF- $\kappa \mathrm{B}$ signaling by preventing $\mathrm{I} \kappa \mathrm{B} \alpha$ degradation and is reported to reduce synovial macrophage inflammatory activity in experimental murine collagen arthritis [44] but, again, is not specifically targeted to the macrophage. Thalidomide likewise suppresses clinical activity of systemic onset juvenile RA [45], and leads to monocyte apoptosis in vitro through actions on AKT-1 [46] and NF- $\kappa$ B signaling [47], but with the attendant threat of teratogenesis and other serious off-target effects. Developing macrophage-specific NF- $\kappa \mathrm{B}$ suppressants may also have to contend with internal redundancy, with RelA and cRel able to serve similar functions for apoptosis suppression in haematopoietic cells [48].

\section{Conclusions}

We were able to confirm that the potent NF- $\kappa \mathrm{B}$ activator, TNF- $\alpha$, counters MTX-induced apoptosis in primary murine macrophages. A less potent activator, RANKL, could not. Neither could the primary macrophage differentiation and survival factor, M-CSF, which we found did not activate NF- $\kappa \mathrm{B}$ signaling. However, MTX did not suppress either constitutive or induced NF- $\kappa$ B signaling, ruling out a direct apoptotic action through NF- $\kappa$ B inhibition. These findings provide an additional explanation for the clinical complementarity between MTX and antiTNF- $\alpha$ treatments for rheumatoid arthritis.

\section{Abbreviations}

7-AAD: 7-aminoactinomycin D; AICAR: 5-aminoimidazole-4-carboxamide ribonucleotide; BAY: BAY11-7085; BMDM: bone marrow-derived

macrophages; DISC: death-inducing signaling complex; DMEM: Dulbecco's Modified Eagle Medium; ERK: extracellular signal-regulated kinase; FCS: foetal calf serum; FLIP FLICE: inhibitory protein; GADD45ß: growth arrest and DNA damage inducible protein; GM-CSF: Granulocyte macrophage-colony stimulating factor; IKB: inhibitor of NF-KB; IAP: inhibitors of apoptosis; IL-1, interleukin-1; JNK: jun N-terminal kinase; MAPK: mitogens-activated protein kinase; M-CSF: macrophage colony stimulating factor; Mn-SOD: manganese superoxide dismutase; MTT: 3-(4,5-Dimethylthiazol-2-yl)-2,5-

diphenyltetrazolium bromide; MTX: methotrexate; NF-KB: nuclear factorkappa-light-chain-enhancer of activated B cells; PAR: parthenolide; PDGF: platelet-derived growth factor; PI3K/KT: phosphatidylinositol-3-kinase/ protein kinase B; RANKL: receptor activator of NF-KB; RIP: receptor-interacting protein; TNF-a: tumor necrosis factor-alpha; TRAF TNF: receptor associated factor; VEGF: vascular endothelial growth factor; XIAP: X-linked inhibitor of apoptosis protein.

\section{Acknowledgements}

The authors acknowledge the facilities, scientific and technical assistance of the Australian Microscopy \& Microanalysis Research Facility at the Centre for Microscopy, Characterisation and Analysis, The University of Western Australia, a facility funded by The University, State and Commonwealth Governments. We thank Dr. Kathy Hill-Miller for technical support with flow cytometry.

Supported by National Health and Medical Research Council (Australia) Project Grant No. 572638 and an Australian Commonwealth Postgraduate Scholarship awarded to Susan ZY Lo.

\section{Authors' contributions}

$\mathrm{SL}$ performed the experiments and co-wrote the manuscript. DJ conceived of the study and co-wrote the manuscript. All authors were involved in the design of the study and interpretation of results.

\section{Competing interests}

The authors declare that they have no competing interests.

Received: 31 August 2010 Revised: 1 February 2011

Accepted: 15 February 2011 Published: 15 February 2011

\section{References}

1. Gordon S, Taylor PR: Monocyte and macrophage heterogeneity. Nat Rev Immunol 2005, 5:953-964. 
2. Kuhlmann T, Bitsch A, Stadelmann C, Siebert H, Bruck W: Macrophages are eliminated from the injured peripheral nerve via local apoptosis and circulation to regional lymph nodes and the spleen. J Neurosci 2001, 21:3401-3408.

3. Smith MD, Weedon H, Papangelis V, Walker J, Roberts-Thomson PJ, Ahern MJ: Apoptosis in the rheumatoid arthritis synovial membrane: modulation by disease-modifying anti-rheumatic drug treatment. Rheumatology (Oxford) 2010, 49:862-875.

4. Catrina Al, Trollmo C, af Klint E, Engstrom M, Lampa J, Hermansson Y, Klareskog L, Ulfgren AK: Evidence that anti-tumor necrosis factor therapy with both etanercept and infliximab induces apoptosis in macrophages, but not lymphocytes, in rheumatoid arthritis joints: extended report. Arthritis Rheum 2005, 52:61-72.

5. Smeets TJ, Kraan MC, van Loon ME, Tak PP: Tumor necrosis factor alpha blockade reduces the synovial cell infiltrate early after initiation of treatment, but apparently not by induction of apoptosis in synovial tissue. Arthritis Rheum 2003, 48:2155-2162.

6. Lugering A, Schmidt M, Lugering N, Pauels HG, Domschke W, Kucharzik T: Infliximab induces apoptosis in monocytes from patients with chronic active Crohn's disease by using a caspase-dependent pathway. Gastroenterology 2001, 121:1145-1157.

7. Taylor PC, Peters AM, Paleolog E, Chapman PT, Elliott MJ, McCloskey R, Feldmann M, Maini RN: Reduction of chemokine levels and leukocyte traffic to joints by tumor necrosis factor alpha blockade in patients with rheumatoid arthritis. Arthritis Rheum 2000, 43:38-47.

8. Gehr G, Gentz R, Brockhaus M, Loetscher H, Lesslauer W: Both tumor necrosis factor receptor types mediate proliferative signals in human mononuclear cell activation. J Immunol 1992, 149:911-917.

9. Yuan J: Transducing signals of life and death. Curr Opin Cell Biol 1997, 9:247-251.

10. Beg AA, Baltimore D: An essential role for NF-kappaB in preventing TNFalpha-induced cell death. Science 1996, 274:782-784

11. Pennington KN, Taylor JA, Bren GD, Paya CV: IkappaB kinase-dependent chronic activation of NF-kappaB is necessary for p21(WAF1/Cip1) inhibition of differentiation-induced apoptosis of monocytes. Mol Cell Biol 2001, 21:1930-1941.

12. Handel ML, McMorrow LB, Gravallese EM: Nuclear factor-kappa B in rheumatoid synovium. Localization of p50 and p65. Arthritis Rheum 1995, 38:1762-1770.

13. Herman S, Zurgil N, Deutsch M: Low dose methotrexate induces apoptosis with reactive oxygen species involvement in T lymphocytic cell lines to a greater extent than in monocytic lines. Inflamm Res 2005, 54:273-280.

14. Weinblatt ME, Keystone EC, Furst DE, Moreland LW, Weisman MH, Birbara CA, Teoh LA, Fischkoff SA, Chartash EK: Adalimumab, a fully human anti-tumor necrosis factor alpha monoclonal antibody, for the treatment of rheumatoid arthritis in patients taking concomitant methotrexate: the ARMADA trial. Arthritis Rheum 2003, 48:35-45.

15. Wessels JA, Huizinga TW, Guchelaar HJ: Recent insights in the pharmacological actions of methotrexate in the treatment of rheumatoid arthritis. Rheumatology (Oxford) 2008, 47:249-255.

16. Hasko G, Cronstein BN: Adenosine: an endogenous regulator of innate immunity. Trends Immunol 2004, 25:33-39.

17. Koizumi S, Curt GA, Fine RL, Griffin JD, Chabner BA: Formation of methotrexate polyglutamates in purified myeloid precursor cells from normal human bone marrow. J Clin Invest 1985, 75:1008-1014.

18. Xu J, Tan JW, Huang L, Gao XH, Laird R, Liu D, Wysocki S, Zheng MH: Cloning, sequencing, and functional characterization of the rat homologue of receptor activator of NF-kappaB ligand. J Bone Miner Res 2000, 15:2178-2186.

19. Yip $\mathrm{KH}$, Zheng MH, Feng $H T$, Steer $J H$, Joyce DA, Xu J: Sesquiterpene lactone parthenolide blocks lipopolysaccharide-induced osteolysis through the suppression of NF-kappaB activity. J Bone Miner Res 2004 19:1905-1916.

20. Yip KH, Zheng MH, Steer JH, Giardina TM, Han R, Lo SZ, Bakker AJ, Cassady Al, Joyce DA, Xu J: Thapsigargin modulates osteoclastogenesis through the regulation of RANKL-induced signaling pathways and reactive oxygen species production. J Bone Miner Res 2005, 20:1462-1471.

21. Steer JH, Kroeger KM, Abraham LJ, Joyce DA: Glucocorticoids suppress tumor necrosis factor-alpha expression by human monocytic THP-1 cells by suppressing transactivation through adjacent NF-kappa B and c-Jun- activating transcription factor- 2 binding sites in the promoter. $J \mathrm{BiO}$ Chem 2000, 275:18432-18440.

22. Rioja I, Hughes FJ, Sharp CH, Warnock LC, Montgomery DS, Akil M, Wilson AG, Binks MH, Dickson MC: Potential novel biomarkers of disease activity in rheumatoid arthritis patients: CXCL13, CCL23, transforming growth factor alpha, tumor necrosis factor receptor superfamily member 9, and macrophage colony-stimulating factor. Arthritis Rheum 2008, 58:2257-2267.

23. Bruce-Gregorios JH, Soucy D, Chen MG, Benson N: Effect of methotrexate on cell cycle and DNA synthesis of astrocytes in primary culture: flow cytometric studies. J Neuropathol Exp Neurol 1991, 50:63-72.

24. Hamilton RA, Kremer JM: Why intramuscular methotrexate may be more efficacious than oral dosing in patients with rheumatoid arthritis. $\mathrm{Br} J$ Rheumatol 1997, 36:86-90.

25. Raschke WC, Baird S, Ralph P, Nakoinz I: Functional macrophage cell lines transformed by Abelson leukemia virus. Cell 1978, 15:261-267.

26. Pagliari LJ, Perlman H, Liu H, Pope RM: Macrophages Require Constitutive NF-kappa B Activation To Maintain A1 Expression and Mitochondrial Homeostasis. Mol Cell Biol 2000, 20:8855-8865.

27. Fiers W: Tumor necrosis factor. Characterization at the molecular, cellular and in vivo level. FEBS Lett 1991, 285:199-212.

28. Natoli G, Costanzo A, Guido F, Moretti F, Bernardo A, Burgio VL, Agresti C, Levrero M: Nuclear factor kB-independent cytoprotective pathways originating at tumor necrosis factor receptor-associated factor 2. $J$ Biol Chem 1998, 273:31262-31272.

29. Pincheira R, Castro AF, Ozes ON, Idumalla PS, Donner DB: Type 1 TNF receptor forms a complex with and uses Jak2 and c-Src to selectively engage signaling pathways that regulate transcription factor activity. $J$ Immunol 2008, 181:1288-1298.

30. Place RF, Haspeslagh D, Giardina C: Induced stabilization of IkappaBalpha can facilitate its re-synthesis and prevent sequential degradation. J Cell Physiol 2003, 195:470-478.

31. Nasu K, Nishida M, Ueda T, Yuge A, Takai N, Narahara H: Application of the nuclear factor-kappaB inhibitor BAY 11-7085 for the treatment of endometriosis: an in vitro study. Am J Physiol Endocrinol Metab 2007, 293: E16-23.

32. Egberts $J H$, Cloosters $V$, Noack A, Schniewind B, Thon L, Klose S, Kettler B, von Forstner C, Kneitz C, Tepel J, Adam D, Wajant H, Kalthoff H, Trauzold A: Anti-tumor necrosis factor therapy inhibits pancreatic tumor growth and metastasis. Cancer Res 2008, 68:1443-1450.

33. Pettit AR, Walsh NC, Manning C, Goldring SR, Gravallese EM: RANKL protein is expressed at the pannus-bone interface at sites of articular bone erosion in rheumatoid arthritis. Rheumatology (Oxford) 2006, 45:1068-1076.

34. Ang ES, Pavlos NJ, Chai LY, Qi M, Cheng TS, Steer JH, Joyce DA, Zheng MH, $\mathrm{Xu}$ J: Caffeic acid phenethyl ester, an active component of honeybee propolis attenuates osteoclastogenesis and bone resorption via the suppression of RANKL-induced NF-kappaB and NFAT activity. J Cell Physiol 2009, 221:642-649.

35. Majumdar S, Aggarwal BB: Methotrexate suppresses NF-kappaB activation through inhibition of IkappaBalpha phosphorylation and degradation. J Immunol 2001, 167:2911-2920.

36. Nakshatri H, Goulet RJ Jr: NF-kappaB and breast cancer. Curr Probl Cancer 2002, 26:282-309.

37. Feldmann M, Brennan FM, Maini RN: Role of cytokines in rheumatoid arthritis. Annu Rev Immunol 1996, 14:397-440.

38. Kotake S, Udagawa N, Hakoda M, Mogi M, Yano K, Tsuda E, Takahashi K, Furuya T, Ishiyama S, Kim KJ, Saito S, Nishikawa T, Takahashi N, Togari A, Tomatsu T, Suda T, Kamatani N: Activated human T cells directly induce osteoclastogenesis from human monocytes: possible role of T cells in bone destruction in rheumatoid arthritis patients. Arthritis Rheum 2001, 44:1003-1012.

39. Asagiri $M$, Takayanagi $H$ : The molecular understanding of osteoclast differentiation. Bone 2007, 40:251-264.

40. Ikeda F, Matsubara T, Tsurukai T, Hata K, Nishimura R, Yoneda T: JNK/c-Jun signaling mediates an anti-apoptotic effect of RANKL in osteoclasts. J Bone Miner Res 2008, 23:907-914.

41. Schett G, David JP: Denosumab-a novel strategy to prevent structural joint damage in patients with RA? Nat Clin Pract Rheumatol 2008, 4:634-635.

42. Yasuda Y, Saito M, Yamamura T, Yaguchi T, Nishizaki T: Extracellular adenosine induces apoptosis in Caco-2 human colonic cancer cells by 
activating caspase-9/-3 via A(2a) adenosine receptors. J Gastroenterol 2009, 44:56-65.

43. Gross A, MCDonnell JM, Korsmeyer SJ: BCL-2 family members and the mitochondria in apoptosis. Genes Dev 1999, 13:1899-1911.

44. Lee SW, Kim JH, Park YB, Lee SK: Bortezomib attenuates murine collageninduced arthritis. Ann Rheum Dis 2009, 68:1761-1767.

45. Lehman TJ, Schechter SJ, Sundel RP, Oliveira SK, Huttenlocher A, Onel KB: Thalidomide for severe systemic onset juvenile rheumatoid arthritis: A multicenter study. J Pediatr 2004, 145:856-857.

46. Gockel HR, Lugering A, Heidemann J, Schmidt M, Domschke W, Kucharzik T, Lugering $\mathrm{N}$ : Thalidomide induces apoptosis in human monocytes by using a cytochrome c-dependent pathway. I Immunol 2004, 172:5103-5109.

47. Majumdar S, Lamothe B, Aggarwal BB: Thalidomide suppresses NF-kappa B activation induced by TNF and $\mathrm{H} 2 \mathrm{O} 2$, but not that activated by ceramide, lipopolysaccharides, or phorbol ester. J Immunol 2002, 168:2644-2651.

48. Grossmann M, Metcalf D, Merryfull J, Beg A, Baltimore D, Gerondakis S: The combined absence of the transcription factors Rel and RelA leads to multiple hemopoietic cell defects. Proc Natl Acad Sci USA 1999, 96:11848-11853.

doi:10.1186/ar3248

Cite this article as: Lo et al:: Tumor necrosis factor-alpha promotes survival in methotrexate-exposed macrophages by an NF- $\kappa$ B-dependent pathway. Arthritis Research \& Therapy 2011 13:R24.

\section{Submit your next manuscript to BioMed Central} and take full advantage of:

- Convenient online submission

- Thorough peer review

- No space constraints or color figure charges

- Immediate publication on acceptance

- Inclusion in PubMed, CAS, Scopus and Google Scholar

- Research which is freely available for redistribution

Submit your manuscript at www.biomedcentral.com/submit 